In connection with the above, it is substantiated that the terms «security» and «protection» of state secrets are not interchangeable. The measures of protection are evidence of the effectiveness of the protection of activities, so we should talk about «protection of state secrets», as an indicator of the effectiveness and efficiency of functioning of the system of state secrets. The author expresses the opinion that the distinction between the terms «security and protection» of state secrets lies in the functional purpose, namely, the object of security is a state secret, and protection - activity, which provides legislation in the field of state secrets.

DOI: 10.33.66.3/2524-017X-2019-10-287-292

УДК 343

\author{
Олександр Володимирович Василенко, \\ аспірант відділу проблем кримінального права, \\ кримінології та судоустрою Інституту держави і права \\ ім. В. М. Корецького НАН України
}

\title{
ДАНІ 3 СИСТЕМИ ЕЛЕКТРОННИХ ПЛАТЕЖІВ ЯК ПРЕДМЕТ ЗЛОЧИНУ
}

Як відомо, злочини $є$ в певному сенсі динамічним явищем, яке зазнає значних змін в процесі розвитку людської цивілізації. Оскільки задля покращення якості суспільного життя та раціоналізації різноманітних процесів вчені у різних галузях знань постійно здійснюють все нові і нові наукові відкриття та удосконалення вже існуючих винаходів, видозмінюються і шляхи неправомірної людської поведінки, спрямованої на вчинення злочинів.

Важливим аспектом існування, як фізичних, так і юридичних осіб, $є$ питання фінансової безпеки. 3 кінця двадцятого століття все більшими темпами зростає кількість фінансових операцій, які здійснюються за допомогою систем електронних платежів. Відповідно все частіше відбуваються злочинні посягання на незаконне заволодіння даними, що оброблюються електронними платіжними системами в процесі їхньої роботи. Разом з тим, можна констатувати, що предмет злочинного посягання у вищезазначеній категорії кримінальних правопорушень, в наукових дослідженнях розглядається в недостатньому обсязі. Зокрема, на нашу думку, в літературі спостерігаються два підходи до дослідження даних систем електронних платежів, як предмета кримінальних правопорушень: 1) «звужений» підхід асоціює предмет злочинного посягання в електронних платіжних системах 3 поняттям «електронні гроші», не розглядаючи інші категорії даних, таких, як: персональні дані користувачів, дані, що становлять комерційну, службову або державну таємницю тощо; 2) «розширений» підхід розглядає дані системи електронних платежів в контексті ототожнення цього предмета із предметами, які зазвичай $є$ складовими родового об'єкта злочинів, передбачених розд. XVI Кримінального кодексу України (далі - КК України) «Злочини у сфері використання електронно-обчислювальних машин (комп'ютерів), систем та комп'ютерних мереж». На нашу думку, обидва вищезазначені підходи не в повному обсязі відображають характеристику даних систем електронних платежів як предмета злочинного посягання, а саме недостатньою мірою виокремлюють і персоніфікують предмет даних систем електронних платежів як комплексне багатоскладове поняття.

Аналіз останніх досліджень і публікацій. Проблема розуміння даних систем електронних платежів як предмета злочинів лежить в площині трьох груп кримінальних правопорушень, а саме: злочинів проти власності, злочинів у сфері господарської діяльності та злочинів у сфері використання електронно-обчислювальної техніки. Найбільш вагомий внесок в іiї вивчення зробили такі вітчизняні науковці, як П. П. Андрушко, В. І. Борисов, В. К. Грищук, О. О. Дудоров, В. Я. Тацій, П. Л. Фріс, М. І. Хавронюк та ін.

Метою статті є встановлення науково обгрунтованих підходів до розуміння правової природи даних систем електронних платежів як предмета злочину. 
Для того щоб дати повну характеристику даних електронних платіжних систем як предмета злочинного посягання, необхідно визначити, факультативною ознакою яких саме об'єктів кримінальних правопорушень вони виступають.

Як влучно зазначив В. О. Навроцький - правильне визначення об'єкта злочину має і своє практичне значення, оскільки помилка у ньому унеможливлює здійснення правильної кримінальноправової кваліфікації вчиненого діяння $[1$, с. 26]. Дані електронно-обчислювальних систем $\epsilon$ багатоскладовим предметом злочину, оскільки включають в себе та об'єднують доволі велику кількість різних типів інформації, що відтворюються та використовується в процесі обробки та виконання операцій в системах електронних платежів.

Як вказував М. Ш. Левіашвілі, науково обгрунтована класифікація об'єктів злочину дозволяє правильно визначити місце конкретного об'єкта в загальній системі суспільних відносин, що $є$ визначальним для точної кваліфікації злочинів [2, с. 95]. Таким чином, вбачається за необхідне провести класифікацію даних електронних платіжних систем як предметів кримінальних правопорушень 3 урахуванням особливостей родових об'єктів кожного конкретного складу кримінального правопорушення, в якому можуть бути задіяні такі дані.

Предметом злочину в класичній теорії кримінального права визнаються речі матеріального світу, діючи на які, особа посягає на цінності (блага), що належать суб'єктам суспільних відносин [3, c. 127]. Дані систем електронних платежів зазвичай виступають предметом корисливих злочинів, однак, на нашу думку, у зв'язку з високим рівнем кібернетизації суспільного життя, такі дані не $\epsilon$ предметом якоїсь конкретної категорії кримінальних правопорушень, а можуть виступати як предмет злочинів, передбачених різними розділами КК України.

Так, дані системи електронних платежів можуть бути предметом таких злочинів, як: шахрайство (ст. 190 КК України), тобто заволодіння чужим майном (в даному випадку електронними грошима або грошовим сурогатом) шляхом обману чи зловживання довірою; незаконні дії з документами на переказ, платіжними картками та іншими засобами доступу до банківських рахунків, електронними грошима, обладнанням для їх виготовлення (ст. 200 КК України), тобто підробка документів на переказ, платіжних карток чи інших засобів доступу до банківських рахунків, електронних грошей, а так само придбання, зберігання, перевезення, пересилання з метою збуту підроблених документів на переказ, платіжних карток або їх використання чи збут, а також неправомірний випуск або використання електронних грошей. При цьому в тексті КК України роз'яснено, що під документами на переказ слід розуміти як документ в паперовому, так і в електронному вигляді, що використовується банками чи їх клієнтами для передачі доручень або інформації на переказ грошових коштів між суб'єктами переказу грошових коштів (розрахункові документи, документи на переказ готівкових коштів, а також ті, що використовуються при проведенні міжбанківського переказу та платіжного повідомлення, інші). Таким чином, в нормі вказаної статті міститься пряме посилання на електронні документи та електронні гроші, які своєю чергою виступають даними систем електронних платежів.

Іншою категорією кримінальних правопорушень, предметом якої можуть виступати дані системи електронних платежів $є$ злочини, передбачені розділ. XVI КК України, а саме: несанкціоноване втручання в роботу електронно-обчислювальних машин (комп'ютерів), автоматизованих систем, комп'ютерних мереж чи мереж електрозв'язку, що призвело до витоку, втрати, підробки, блокування інформації, спотворення процесу обробки інформації або до порушення встановленого порядку іiї маршрутизації (ст. 361 КК України); створення з метою використання, розповсюдження або збуту, а також розповсюдження або збут шкідливих програмних чи технічних засобів, призначених для несанкціонованого втручання в роботу електронно-обчислювальних машин (комп'ютерів), автоматизованих систем, комп'ютерних мереж чи мереж електрозв'язку (ст. 361-1 КК України); несанкціоновані збут або розповсюдження інформації з обмеженим доступом, яка зберігається в електронно-обчислювальних машинах (комп'ютерах), автоматизованих системах, комп'ютерних мережах або на носіях такої інформації, створеної та захищеної відповідно до чинного законодавства (ст. 361-2 КК України); несанкціоновані зміна, знищення або блокування інформації, яка оброблюється в електронно-обчислювальних машинах (комп'ютерах), автоматизованих системах чи комп'ютерних мережах або несанкціоновані перехоплення або копіювання такої інформації, якщо це призвело до ії̈ витоку, вчинені особою, яка має право доступу до такої інформації (ст. 362 КК України); порушення правил експлуатації електронно-обчислювальних машин (комп’ютерів), 
автоматизованих систем, комп'ютерних мереж чи мереж електрозв'язку або порядку чи правил захисту інформації, яка в них оброблюється, якщо це заподіяло значну шкоду, вчинені особою, яка відповідає за їх експлуатацію (ст. 363 КК України) [4].

Отож розглянемо окремо категорії злочинів, предметом в яких можуть виступати дані систем електронних платежів.

Ряд науковців визначають родовим об'єктом злочинів розд. XVI КК України суспільні відносини у сфері безпеки комп'ютерної інформації і нормального функціонування електронно-обчислювальних машин (комп'ютерів), їх систем та комп'ютерних мереж [5, с. 427].

Якщо проаналізувати підхід до визначення предмета злочинів, що посягають на безпеку використання комп'ютерних систем та на дані систем електронних платежів зокрема, можна констатувати, що практика визначення предметів злочинів цієї категорії в світі є неоднаковою. Відповідно до положень Кримінального кодексу штату Юта (США) під предметом таких злочинів розуміються «відчутні та невідчутні елементи, що поріднені з комп'ютерами, комп'ютерними системами та мережами» [6]. На нашу думку, слід дотримуватися позиції, що в переважній більшості випадків предметом цієї категорії кримінальних правопорушень є нематеріальні дані, які в процесі вчинення правопорушення можуть набувати матеріальної форми (наприклад, зняття готівкових коштів з банкомата тощо), однак, на першочерговому етапі вчинення такої категорії правопорушень безпосереднім предметом злочинного посягання є інформація, що перебуває у віртуальному (цифровому) стані та не має реального відображення в матеріальному світі.

Аналізуючи думки вітчизняних вчених щодо предмета злочинів, передбачених розділ. XVI КК України, можна виокремити декілька позицій з вказаного питання, зокрема А. М. Ришелюк визначає такі предмети злочинного посягання за вказаною категорією як: 1) автоматизовані електронно-обчислювальні машини (комп'ютери, АЕОМ), у тому числі персональні; 2) їх системи; 3) комп'ютерні мережі» [7, с. 583]. В. Г. Гончаренко визначає предмет вказаної категорії злочинів як кілька елементів сфери електронного інформаційного забезпечення життя суспільства: електронно-обчислювальні машини (EOM); програмні матеріали, що забезпечують нормальне функціонування ЕОМ; носії інформації; системи ЕОМ та комп'ютерні мережі [8, с. 871].

Разом $з$ тим можемо констатувати, що всі вищезазначені позиції уникають питання віднесення до безпосереднього предмета злочинів, передбачених розділ. XVI КК України даних в електронному вигляді. На нашу думку, таке упущення з боку вітчизняних науковців є значним прорахунком, адже в деяких випадках саме дані електронних систем (в тому числі і платіжних) виступають безпосереднім предметом злочинного посягання, а комп'ютерна техніка в таких випадках лишається лише побічним інструментом зберігання таких даних і сама по собі не становить цілі вчинення кримінального правопорушення. Невизнання комп'ютерної інформації (даних) окремими фахівцями предметом злочину обумовлено «матеріалістичним» підходом класичної теорії кримінального права до визначення предмета злочину як певних матеріальних цінностей. В той час, комп'ютерні бази даних, дані, що використовуються при обробці та виконанні певних видів операцій, в тому числі операцій в електронних платіжних системах, та інші види інформації в будь-яких операційних системах є предметом віртуальним, тобто умовним, фізично відсутнім, але таким, що може бути відтворений за допомогою спеціальних методів виведення та дешифрування інформації.

Аналізуючи категорії кримінальних правопорушень, предметом яких виступають дані систем електронних платежів, можемо відзначити, що переважну більшість таких протиправних діянь тим чи іншим чином мають корисливу мету. Однак, на відміну від об' єктів матеріального світу (речей), що є традиційними предметами злочинів проти власності, грошові кошти в системах електронних платежів не мають матеріальної форми. Відтак, їх викрадення або підробку (підміну), як правило, важче своєчасно ідентифікувати.

Саме законодавче формулювання системи електронних платежів є, на нашу думку, недосконалим, оскільки в першу чергу Закон України «Про платіжні системи та переказ коштів в Україні» (далі - Закон) вживає формулювання системи електронних платежів як державної банківської платіжної системи, що забезпечує проведення міжбанківського переказу через рахунки, відкриті в Національному банку України. Таким чином, Закон встановлює визначення системи електронних платежів як внутрішньої системи НБУ, не наводячи загального визначення системи електронних платежів. Натомість відповідно до п. 1.29 ст. 1 Закону можна відшукати визначення платіжної системи, тобто платіжної організації, учасників платіжної системи та сукупності відносин, що ви- 
никають між ними при проведенні переказу коштів [9]. При цьому проведення переказу коштів $\epsilon$ обов' язковою функцією, що має виконувати платіжна система. Таким чином, діюче законодавство України не дає чіткого (загального) формулювання поняття системи електронних платежів, однак таке поняття може бути визначене в спрощеному вигляді як система зв'язку та взаємодії між клієнтом (фізичною або юридичною особою) та банківською установою, за допомогою якої клієнт має можливість здійснювати банківські операції, використовуючи спеціальне програмне забезпечення.

Характеризуючи корисливі злочини, предметом яких можуть виступати дані систем електронних платежів, варто виокремити особливу категорію даних, яка найчастіше виступає предметом злочинного посягання у зазначеній категорії правопорушень, а саме - електронні гроші. Однією з особливостей електронних грошей $є$ їх поділ на види, що базується на технічному походженні електронних грошей. Залежно від електронного носія останні можуть бути двох видів: електронні гроші на основі карток та електронні гроші, генеровані на жорсткому диску комп'ютера $[10$, с. $47 ; 11$, с. $400-402 ; 12$, с. $8 ; 13$, с. 480$]$.

Згідно з П. 15.1 ст. 15 Закону електронні гроші визначено як одиниці вартості, які зберігаються на електронному пристрої, приймаються як засіб платежу особами іншими, ніж особа, яка їх випускає, і є грошовим зобов'язанням цієї особи, що виконується в готівковій або безготівковій формі. Пункт 1.3 Положення про електронні гроші в Україні, затвердженого постановою Правління Національного банку України від 4 листопада 2010 р. № 481, дещо звужує трактування та закріплює таке положення: електронні гроші - одиниці вартості, які зберігаються на електронному пристрої, приймаються як засіб платежу іншими, ніж емітент, особами і є грошовим зобов'язанням емітента [14]. Аналізуючи наведені визначення, П. С. Берзін виокремлює такі ознаки цього поняття, як: а) за своєю правовою природою електронні гроші становлять собою грошове зобов'язання певної особи, яка здійснює їх випуск, тобто є зобов’язанням боржника сплатити кредитору певну грошову суму відповідно до цивільного правочину (договору) та на певних підставах, передбачених законодавством України; б) їх матеріальним виразом є одиниця вартості, що зберігається на електронному пристрої у формі певного технічного символу; в) приймаються як засоби платежу [15, с. 13-16]. Запропоновані ознаки дають змогу зробити висновок про те, що електронні гроші мають самостійну економічну цінність, з огляду на це під випуском електронних грошей необхідно розуміти лише зміну форми виразу коштів із готівкових чи безготівкових на відповідні одиниці вартості в електронному вигляді, що зберігаються на електронному пристрої, і навпаки, при погашенні змінюється форма вказаних одиниць вартості з електронної форми на готівкову чи безготівкову, з розрахунку один до одного. Таким чином, під час свого перебування в електронному вигляді електронні гроші можуть відображатися як дані електронної платіжної системи, а відповідно можуть бути предметом певних видів злочинів.

Дефініція поняття «електронні гроші» міститься в Директиві 2009/110/ЕС Європейського парламенту та Ради щодо започаткування та здійснення діяльності установами-емітентами електронних грошей та пруденційний нагляд за ними, що вносить зміни до Директиви 2005/60/EC та 2006/48/ $\mathrm{EC}$, яка закріплює, що електронні гроші означають грошову вартість, як представлено у вимозі до емітента, які зберігаються на електронному пристрої, в тому числі магнітному, випускаються для отримання коштів з метою здійснення платіжних операцій та приймаються фізичною або юридичною особою, відмінною від установи-емітента електронних грошей. Таким чином, електронні гроші можна віднести до особливого роду безготівкових грошових коштів, а отже, вони можуть, зокрема виступати предметом злочинів проти власності [16].

Іще одним типом даних електронних платіжних систем, що може виступати як предмет злочину, $€$ різноманітні групи даних в персоніфікованих транзакціях, що містять будь-яку конфіденційну, охоронювану законом інформацію, а саме: банківську, комерційну, державну таємницю, персональні дані клієнта тощо. Крім того, не слід випускати з поля зору типи даних, що являють елементи електронної платіжної системи на програмному рівні, тобто сам по собі програмний код, 3 якого складається та чи інша електронна платіжна система. Такі дані можуть становити предмет злочинів, пов'язаних із кібернетичною безпекою.

Висновки: 1) Дані систем електронних платежів є багатоскладовим та різноплановим предметом злочинів, що обумовлюється як різною направленістю злочинних посягань за метою, так і неоднорідністю даних систем електронних платежів самих по собі. 2) При характеризуванні даних систем електронних платежів як предметів злочину не слід звужувати відповідну категорію до яко- 
гось окремого виду або категорії кримінальних правопорушень, оскільки з розвитком технічного прогресу та еволюцією суспільних відносин різноманітні електронно-обчислювальні системи (в тому числі і системи електронних платежів) тісно увійшли до повсякденного життя людини, таким чином, 3’явилася досить велика кількість складів кримінальних правопорушень, що тим чи іншим чином зачіпають дані електронно-обчислювальних систем як предмет злочинного посягання. 3) Законодавча база для регулювання систем електронних платежів в Україні має ряд неточностей та прогалин, зокрема не надано загального законодавчого визначення поняття електронної платіжної системи та до кінця не врегульоване питання із правовим статусом такого типу даних, як криптовалюта. Задля удосконалення методик розслідування економічних, господарських, майнових злочинів та злочинів у сфері кібернетичної безпеки слід продовжувати подальшу теоретичну розробку та опрацювання питань, пов'язаних із врахуванням інноваційного технічного прогресу суспільного життя, зокрема щодо правового статусу різних типів даних у електронно-обчислювальних системах (в тому числі і в системах електронних платежів).

\section{Список використаних джерел}

1. Навроцький В. О. Теоретичні проблеми кримінально-правової кваліфікації / В. О. Навроцький. - К. : Атіка, 1999. - 464 с. - (Державний університет імені Івана Франка).

2. Левиашвили М. Ш. Объект уголовно-правовой охраны и его значение для классификации преступлений / М. Ш. Левиашвили // Уголовно-правовые исследования : сборник, посвященный 80-летию со дня рождения Т. В. Церетели: [Материалы всесоюзной конференции; 2-4 ноября 1983 г., Тбилиси / [Редкол. В. Г.Макашвили (гл. ред.) и др.] / М. Ш. Левиашвили. - Тбилиси : Мецниереба, 1987. - С. 94-103.

3. Кравиов С. Ф. Предмет преступления : автореф. дисс. ... канд. юрид. наук. 12.00.08./Ленинградский государственный университет им. А.А.Жданова. - Ленинград,1976. - 19 с.

4. Кримінальний кодекс України [Електронний ресурс] // Офіційний сайт Верховної Ради України. - 2001. - Режим доступу : https://zakon.rada.gov.ua/laws/show/2341-14/conv/print

5. Кримінальне право України: Особлива частина: підруч. / М. І. Бажанов, Ю. В. Баулін, В. І. Борисов та ін.; За ред. проф. М. І. Бажанова , В. В. Сташиса, В. Я. Тація. - 2 ге вид., перероб. і доп. - К. : Юрінком Інтер, 2005. - $544 \mathrm{c}$

6. Utah Criminal Code [Електронний ресурс] - Режим доступу : https://codes.findlaw.com/ut/title-76-utah-criminalcode/\#!tid=NCAC95AD08F7911DBAEB0F162C0EFAF87.

7. Науково-практичний коментар Кримінального кодексу України / за ред. М. І. Мельника, М. І. Хавронюка. 11-те вид., переробл. та допов. - К. : ВД «Дакор», 2019. - 1384 с.

8. Науково-практичний коментар до Кримінального кодексу України. У 2-х т. / За заг. ред. П.П. Андрушка, В. Г. Гончаренка, С. В. Фесенка. - К. : Правова єдність, 2009. - 1588 с.

9. Закон України «Про платіжні системи та переказ коштів в Україні» [Електронний ресурс] // Офіційний сайт Верховної Ради України. - 2001. - Режим доступу : https://zakon.rada.gov.ua/laws/show/2346-14

10. Махаєва О. О. Підходи до регулювання емісії електронних грошей та їх використання // Вісник Української академії банківської справи. - 2005. - № 2(19). - С. 46-51.

11. Тлустий А. О. Електронні гроші та фактори, що визначають їх розвиток // Наукові праці. Економіка. - 2007. Вип. 59. - С. 115-117.

12. Івасів Б. Електронні гроші : можливості, тенденції розвитку та наслідки поширення // Фінансовий ринок України. - 2011. - № 5. - С. 8-9.

13. Трубін I. О. Платіжні системи на основі електронних грошей як складова системи електронних платежів : матер. Всеукр. наук.-практ. конфер. до Дня науки [«Проблеми та перспективи розвитку юридичної науки та освіти в Україні»], (Київ, Нац. авіац. універ., 17 травня 2012 року). - К. : Омега-Л, 2012. - С.479-481.

14. Положення про електронні гроші в Україні, затверджене постановою Правління Національного банку України від 4 листопада 2010 р. № 481 [Електронний ресурс] // Офіційний сайт Верховної Ради України. - 2010. Режим доступу : https://zakon.rada.gov.ua/laws/show/z1336-10.

15. Берзін П. Неправомірний випуск й використання електронних грошей, що вчиняються в системах інтернет-розрахунків (проблеми кримінально-правової кваліфікації) / П. Берзін, М. Куцевич // Вісник Київського національного університету імені Тараса Шевченка. Юридичні науки. - 2013. - № 4 (98).- С. 13-16.

16. Директива 2009/110/ЕС Свропейського Парламенту та Ради щодо започаткування та здійснення діяльності установами - емітентами електронних грошей та пруденційний нагляд за ними, що вносить зміни до Директиви 2005/60/ЕС та 2006/48/ЕС [Електронний ресурс] // Офіційний сайт Верховної Ради України. - 2009. Режим доступу : https://zakon.rada.gov.ua/laws/show/994_a18/conv/print

17. Закон України «Про Національний банк України» [Електронний ресурс] // Офіційний сайт Верховної Ради України. - 1999. - Режим доступу : https://zakon.rada.gov.ua/laws/show/679-14 


\section{References}

1. Navrotskyi V. O. Teoretychni problemy kryminalno-pravovoi kvalifikatsii / V. O. Navrotskyi. - Kyiv : Atika, 1999. 464 s. - (Derzhavnyi universytet imeni Ivana Franka).

2. Levyashvyly M. Sh. Obъekt uholovno-pravovoi okhrand y eho znachenye dlia klassyfykatsyy prestuplenyi / M. Sh. Levyashvyly // Uholovno-pravovыe yssledovanyia: Sbornyk, posviashchennыi 80-letyiu so dnia rozhdenyia T. V. Tseretely: [Materyalb vsesoiuznoi konferentsyy; 2-4 noiabria 1983 h., Tbylysy / [Redkol. V. H. Makashvyly (hl. red.) y dr.] / M. Sh. Levyashvyly. - Tbylysy : Metsnyereba, 1987. - S. 94-103.

3. KravtsovS.F.Predmetprestuplenyia:Avtoreferatdyssertatsyyna soyskanyeuchenoistepeny kandydatayurydycheskykh nauk. 12.00.08./Lenynhradskyi hosudarstvennыi unyversytet ym. A. A.Zhdanova. - Lenynhrad,1976. - $19 \mathrm{~s}$.

4. Kryminalnyi kodeks Ukrainy [Elektronnyi resurs] // Ofitsiinyi sait Verkhovnoi Rady Ukrainy. - 2001. - Rezhym dostupu : https://zakon.rada.gov.ua/laws/show/2341-14/conv/print

5. Kryminalne pravo Ukrainy: Osoblyva chastyna : pidruchnyk / M. I. Bazhanov , Yu. V. Baulin, V. I. Borysov ta in.; Za red. prof. M. I. Bazhanova , V. V. Stashysa, V. Ya. Tatsiia. - 2 he vyd., pererob. i dop. - K. : Yurinkom Inter, 2005. $-544 \mathrm{~s}$

6. Utah Criminal Code [Elektronnyi resurs] - Rezhym dostupu : https://codes.findlaw.com/ut/title-76-utah-criminal-co de/\#!tid=NCAC95AD08F7911DBAEB0F162C0EFAF87

7. Naukovo-praktychnyi komentar Kryminalnoho kodeksu Ukrainy / za red. M. I. Melnyka, M. I. Khavroniuka. - 11-te vyd., pererobl. ta dopov. - Kyiv : VD «Dakor», 2019. - 1384 s.

8. Naukovo-praktychnyi komentar do Kryminalnoho kodeksu Ukrainy. U 2-kh t. / Za zah. red. P. P. Andrushka, V. H. Honcharenka, Ye.V. Fesenka. - K. : Pravova yednist, 2009. - 1588 s.

9. Zakon Ukrainy «Pro platizhni systemy ta perekaz koshtiv v Ukraini» [Elektronnyi resurs] // Ofitsiinyi sait Verkhovnoi Rady Ukrainy. - 2001. - Rezhym dostupu : https://zakon.rada.gov.ua/laws/show/2346-14

10. Makhaieva $O$. O. Pidkhody do rehuliuvannia emisii elektronnykh hroshei ta yikh vykorystannia// Visnyk Ukrainskoi akademii bankivskoi spravy. - 2005. - № 2(19). - C. 46-51.

11. Tlustyi A. O. Elektronni hroshi ta faktory, shcho vyznachaiut yikh rozvytok // Naukovi pratsi. Ekonomika. - 2007. Vyp. 59. - S. 115-117.

12. Ivasiv B. Elektronni hroshi : mozhlyvosti, tendentsii rozvytku ta naslidky poshyrennia // Finansovyi rynok Ukrainy. 2011. - № 5. - S. 8-9.

13. Trubin I. O. Platizhni systemy na osnovi elektronnykh hroshei yak skladova systemy elektronnykh platezhiv : mater. Vseukr. nauk.-prakt. konfer. do Dnia nauky [«Problemy ta perspektyvy rozvytku yurydychnoi nauky ta osvity v Ukraini»], (Kyiv, Nats. aviats. univer., 17 travnia 2012 roku). - K. : Omeha-L, 2012. - S.479-481.

14. Polozhennia pro elektronni hroshi v Ukraini, zatverdzhene postanovoiu Pravlinnia Natsionalnoho banku Ukrainy vid 4 lystopada 2010 r. № 481 [Elektronnyi resurs] // Ofitsiinyi sait Verkhovnoi Rady Ukrainy. - 2010. - Rezhym dostupu : https://zakon.rada.gov.ua/laws/show/z1336-10

15. Berzin $P$. Nepravomirnyi vypusk y vykorystannia elektronnykh hroshei, shcho vchyniaiutsia v systemakh internetrozrakhunkiv (problemy kryminalno-pravovoi kvalifikatsii) / P. Berzin, M. Kutsevych // Visnyk Kyivskoho natsionalnoho universytetu imeni Tarasa Shevchenka. Yurydychni nauky. - 2013. - № 4 (98).- S. 13-16.

16. Dyrektyva 2009/110/ES Yevropeiskoho Parlamentu ta Rady shchodo zapochatkuvannia ta zdiisnennia diialnosti ustanovamy - emitentamy elektronnykh hroshei ta prudentsiinyi nahliad za nymy, shcho vnosyt zminy do Dyrektyvy 2005/60/ES ta 2006/48/ES [Elektronnyi resurs] // Ofitsiinyi sait Verkhovnoi Rady Ukrainy. - 2009. - Rezhym dostupu : https://zakon.rada.gov.ua/laws/show/994_a18/conv/print.

17. Zakon Ukrainy «Pro Natsionalnyi bank Ukrainy» [Elektronnyi resurs] // Ofitsiinyi sait Verkhovnoi Rady Ukrainy. 1999. - Rezhym dostupu : https://zakon.rada.gov.ua/laws/show/679-14

\section{Василенко О. В. Дані з системи електронних платежів як предмет злочину}

У статті відображено проблемні питання оцінки даних електронних платіжних систем як предмета злочину. Проаналізовані основні ознаки предмета як необхідного елемента складу відповідного злочину. Визначено особливості комп'ютерної інформації, як предмета злочинів у сфері банківських платежів. Надано комплексний перелік даних електронних платіжних систем, які можуть виступати як предмет злочину з урахуванням родових ознак кожної конкретної категорії злочинів, де такі дані можуть бути задіяні. Визначено особливі риси таких об'єктів, як «електронні гроші» та «грошові сурогати» як предмета злочину. Одночасно визначено ряд проблемних рис чинного законодавства України, які є середовищем для розвитку злочинної діяльності із інформацією з електронних платіжних систем. Підготовлено ряд висновків та рекомендацій щодо вдосконалення чинного законодавства України для запобігання даній категорії злочинів.

Ключові слова: дані, інформація, електронні платіжні системи, операційні системи, кібербезпека, злочин, кримінальне правопорушення, предмет злочину, криптовалюта, грошовий сурогат. 
Vasilenko O. V. Data on the system of electronic payments as a subject of a crime

The article reflects the problematic issues of evaluating data of electronic payment systems as a crime subject. The main features of the subject as the necessary element of the corresponding crime are analyzed. The peculiarities of computer information as a subject of crimes in the field of bank payments are determined. A comprehensive list of data of electronic payment systems that can act as a crime subject to the generic features of each specific category of crime, where such data may be involved, is provided. Specific features of such objects as «electronic money» and «money surrogates» as the subject of a crime are determined. At the same time a number of problematic features of the current Ukrainian legislation are identified, which are a medium for the development of criminal activities with information from electronic payment systems. A number of conclusions and recommendations have been prepared to improve the current legislation of Ukraine to prevent this category of crimes.

It has been determined that the data of electronic payment systems is a multi-component and diverse subject of crimes, which is conditioned by the different direction of criminal encroachment on purpose, and the heterogeneity of these electronic payment systems by themselves. When describing these electronic payment systems as criminal offenses, the relevant category should not be narrowed down to a particular type or category of criminal offenses, since with the development of technical progress and the evolution of social relations, various electronic computing systems are closely integrated into the everyday life of a person, thus, appeared quite a large number of syllables of criminal offenses, which in one way or another affect the data of electronic computing systems as a subject of a criminal offense. The legislative framework for the regulation of electronic payment systems in Ukraine has some inaccuracies and gaps, in particular, there is no general legal definition of the concept of an electronic payment system, and, to the end, the legal status of such data is not regulated as a cryptographic currency. In order to improve the methods of investigating economic, economic, property crimes and crimes in the field of cybernetic security, further theoretical development and elaboration of issues related to the consideration of innovative technological progress in public life, in particular regarding the legal status of various types of data in electronic computing systems, should be continued.

Key words: data, information, electronic payment systems, operating systems, cyber security, crime, criminal offense, crime subject, crypto currency, money surrogate.

DOI: 10.33.66.3/2524-017X-2019-10-292-298

\title{
УДК 342.5
}

\author{
Пилип Станіславович Демченко, \\ аспірант відділу конституиійного права \\ та місчевого самоврядування Інституту держави і права \\ імені В. М. Корецького НАН Украӥни
}

\section{ПРАВОВИЙ МОНІТОРИНГ \\ ВІТЧИЗНЯНОГО ЗАКОНОДАВСТВА В СФЕРІ РЕАЛІЗАЦІЇ СТРАТЕГІЇ КІБЕРНЕТИЧНОЇ БЕЗПЕКИ УКРАЇНИ}

Постановка проблеми. Питання забезпечення кібернетичної безпеки України обумовлено двома об’єктивними факторами. Впровадження сучасних технологічних досягнень науково-технічного прогресу в діяльності органів державної влади призвело до необхідності забезпечення захисту їх критичної інфраструктури, яке полягає у вироблені технічних, та що не менш важливо, юридичних напрямках. Другий фактор. Відповідно наша держава потребує вироблення сталої Стратегії та законодавчої основи кібербезпеки з окресленням найважливіших питань ії забезпечення. Втім, враховуючи складність технічної термінології та стрімкого розвитку правовідносин в інформаційній сфері, об'єктивним є завдання необхідності проведення правової оцінки відповідного законодавства.

Аналіз останніх досліджень та публікацій. Питання правового моніторингу вітчизняного законодавства неодноразово підіймалося в рамках дослідження юридичної сутності поняття «кібернетична безпека» та захисту інформації у працях вітчизняних спеціалістів з зазначеної проблематики: О. А. Баранов, І. В. Діордіца, Л. В. Срьоміна, Т. А. Костецька, В. А. Ліпкан, В. П. Шеломенцев, 